Горбацкая О. Ю.

O. Y. Gorbatskaya

МОТИВ ЖЕНИТЬБЫ В ПОВЕСТЯХ Н.В. ГОГОЛЯ «ВЕЧЕРА НА ХУТОРЕ БЛИЗ ДИКАНЬКИ»

\title{
THE MOTIVE OF THE MARRIAGE IN N.V. GOGOL'S NOVELS «EVENINGS ON A FARM NEAR DIKANKA»
}

Горбацкая Оксана Юрьевна - кандидат филологических наук, доцент кафедры русского языка как иностранного Амурского гуманитарно-педагогического государственного университета (Россия, г. Комсомольск-на-Амуре). E-mail: oxanagorbazkay@mail.ru.

Ms. Oksana Y. Gorbazkaya - PhD in Philology, associate professor, Department of Russian as the foreign language, Amur State University of Humanities and Pedagogy (Russia, Komsomolsk-on-Amur). E-mail: oxanagorbazkay@mail.ru.

Аннотация. В статье исследован сюжетообразующий мотив женитьбы в пяти повестях сборника Н.В. Гоголя «Вечера на хуторе близ Диканьки». Описано его образно-ситуативное наполнение. Особое внимание в статье уделено изучению мотива женитьбы в мифопоэтическом аспекте: сюжет повестей сравнивается со структурой волшебной сказки, а испытания героев - с прохождением обряда инициации.

Summary. In the article in five stories of N.V. Gogol's collection «Evenings on a farm near Dikanka» the plot motive of the marriage is examined. Its imagery and situational content is described. Special attention is paid to the study of the motive of the marriage in the mythopoetic aspect: the plot of the novels is compared with the structure of the fairy tale, and tests of the characters - with passing through the rite of initiation.

Ключевые слова: мотив женитьбы, волшебная сказка, обряд инициации.

Key words: motive of marriage, fairy tale, rite of initiation.

УДК 82.09

Сборник Н. В. Гоголя «Вечера на хуторе близ Диканьки» состоит из восьми повестей. В пяти повестях сборника («Сорочинская ярмарка», «Вечер накануне Ивана Купала», «Майская ночь, или Утопленница», «Ночь перед Рождеством», «Страшная месть») любовная коллизия составляет ядро сюжета. В начале статьи стоит отметить, что в названных повестях сборника, исследователей, как правило, интересует тема любви и её развитие, однако наше внимание в большей мере будет обращено к мотиву женитьбы и его образно-ситуативному наполнению.

Свадебные сцены изображены в повестях «Сорочинская ярмарка», «Вечер накануне Ивана Купала», свадьбой начинается повесть «Страшная месть», в «Майской ночи, или Утопленнице» главный герой Левко получает согласие на свадьбу с Ганой, в повести «Ночь перед Рождеством» Вакула также добивается согласия на свадьбу с Оксаной от её отца.

Многие исследователи отмечают, что «Вечера...» строят образ светлой мечты о нормальной, естественной жизни, где всё - здоровое, яркое, где торжествует молодость, красота, нравственное начало. Это мир, где бесстрашные, красивые, влюблённые и весёлые парубки так легко добиваются любви ещё более красивых девушек, пламенных и гордых одновременно [4, 37]. Здесь герои женятся по любви, преодолев препятствия, чинимые родителями или обстоятельствами. Однако любовь побеждает препятствия, когда она естественна, в противном случае происходит трагическое разрешение конфликта (Катерина и её отец в «Страшной месте», крах любви Петруся, купленной ценой зла) $[5,20]$.

Мотив женитьбы тесно связан в сборнике с темой создания молодой семьёй своего дома, полного любви и согласия. И. П. Золотусский пишет, что идея дома, родины составляет капитальную идею «Вечеров...». Зло, по мысли Гоголя, безродно, добро всегда имеет дом и родину. 
Горбацкая О. Ю.

МОТИВ ЖЕНИТЬБЫ В ПОВЕСТЯХ Н.В. ГОГОЛЯ «ВЕЧЕРА НА ХУТОРЕ БЛИЗ ДИКАНЬКИ»

О новой хате мечтает Параска в «Сорочинской ярмарке»: «...ещё бы поярче пояс!.. пускай уже, правда, я ему вытку, как перейдём жить в новую хату», дом пана Данилы (до того, как в него явился колдун); в финале «Ночи перед Рождеством» писатель изображает Оксану с младенцем на руках на пороге «размалёванной новой хаты».

На доме всё стоит, домом и строится. Дом, построенный на любви, согласии, стоит долго. Дом, основанный на несчастье, разрушается: разрушается и сгорает хата Петруся и Пидорки в «Вечере накануне Ивана Купала», исчезает в огне замок колдуна, остается в запустении дом сотника в «Майской ночи». В каждом из них обитало преступление $[6,96]$.

И. А. Виноградов рассматривает творчество Н. В. Гоголя через призму христианского мировоззрения, с позиций христианских основ вероучения. Современный исследователь творчества Н. В. Гоголя вступает в дискуссию с И. П. Золотусским. И. А. Виноградов отмечает, что герои «Вечеров...» далеки от идеала истинного христианина: они часто преступают христианские заповеди ради пустых, продиктованных тщеславием и гордостью светских приличий, или ради плотских, греховных удовольствий $[2,21]$. Например, героини повестей испытывают пристрастие к украшениям и нарядам, а герои к хмельному, они не соблюдают постов, обращаются к потусторонним силам.

Женитьба не воспринимается героями как духовный союз, как таинство пред лицом Бога: «заключение брака между героями отнюдь не принадлежит к сфере «возвышенной» жизни, но, напротив, относится к весьма обыденной и «низменной» её области - столь же «низменной», как и заключение прозаической торговой сделки $[2,19]$.

Сравнение брака с торговой сделкой происходит в «Сорочинской ярмарке» («Что? по рукам? А ну-ка, новобранный зять, давай магарычу!» [3, 33]); в «Вечере накануне Ивана Купала» брак тоже является выгодной для отца невесты торговой сделкой; Чуб в «Ночи перед Рождеством» за согласие на свадьбу получает от Вакулы «чудные шапку и пояс». На наш взгляд, утверждение И.А. Виноградова, что женитьба не воспринимается героями как духовный союз не совсем корректно, потому что брак как выгодная торговая сделка осмысливаются отцами невест, Черевиком, Коржом и Чубом, но не женихами.

По мысли И. А. Виноградова, герои для получения согласия на брак со своими возлюбленными преступают христианские заповеди: «В "Вечере накануне Ивана Купала" Петрусь, охваченный любовной страстью, готов на убийство и совершает его. Герой "Ночи перед Рождеством", кузнец Вакула, доведённый до отчаянья капризами красавицы Оксаны, дважды проявляет пагубное малодушие: сначала помышляет о самоубийстве, затем сознательно обращается к нечистой силе» $[2,48]$.

В «Сорочинской ярмарке» и в «Майской ночи, или Утопленнице» герои «добывают» своих «суженных», Грицько обращаясь к помощи нечистой силы - цыгану, а Левко обращаясь к помощи русалке-утопленнице, погубившей свою душу.

Таким образом, мотив женитьбы в «Вечерах...» в интерпретации И. А. Виноградова связан с мотивом преступления христианских заповедей, мотивом греха, отступничества, отпадения человека от данного ему Божественного откровения.

М. Вайскопф в повестях сборника «Вечера на хуторе близ Диканьки» обнаруживает связи с мифологией, фольклорными традициями, а также с масонским творчеством. Мотив женитьбы М. Вайскопф рассматривает в основном через призму масонских представлений Н. В. Гоголя о женитьбе. Исследователь утверждает, что сюжеты повестей включают в себя каноническое путешествие за потусторонним магическим знанием, переосмысленное в том же ракурсе, в каком масонское творчество переработало свой излюбленный сюжет о путешествии души к Премудрости и об обретении потерянного Слова [1,33].

Герои в начале повестей утрачивают слово. Грицько теряет слово-согласие Черевика на брак с Параской, Левко не верит в то, что сумеет получить от отца слово-разрешение на брак с Ганной, Петрусь от Коржа на брак с Пидоркой. «Слово утрачивается героем вместе с сакральной мудростью. Мудрость теряет набожный кузнец, которого постоянно «дурачит» лукавая Оксана: “Стою перед ней, как дурак”. Также теряет мудрость Петрусь: “К чему тут мудрование?”. Левко, 
раньше урезонивавший парубков "не беситься", а теперь решительно отрекается от своей рассудительности: “Я увещевал вас ... но теперь раздумал" < ...>. С этого момента начинается паломничество к демону-проводнику за мудростью, которую герой добывает, проходя испытания» [1, 68-69].

«В финале повестей слово, добытое знание окончательно воплощается и вместе сакрализуется в свадьбе» $[1,105]$.

Исключение составляет повесть «Вечер накануне Ивана Купала»: Петрусь в лесу «постигает было язык цветов и деревьев, сатанинское золото он приобретает именно в обмен на внутреннее сакральное знание. Дома Петрусь «всё силится припомнить что-то... Губы шевелятся, будто хотят произнести какое-то давно “забытое слово” $[1,105]$. Петрусь утрачивает добытое знание, слово, поэтому он обречён на гибель.

М. Вайскопф отмечает, что в ранней гоголевской прозе сильна фольклорная традиция, которая состоит в том, что повести «Вечеров...» воспринимаются как сказки. И. А. Виноградов в работе «Гоголь художник и мыслитель: христианские основы миросозерцания» главу, посвященную повестям «Вечера на хуторе близ Диканьки» называет «Сказки Николая Гоголя»; И. П. Золотусский в книге «Николай Гоголь» пишет: «Стихия сказки, предания, народной песни вольно чувствует себя в этой, может быть, единственно гармоничной книге Гоголя»; сам Гоголь называл повести сборника сказками. Характерно, что сами рассказчики «Вечеров...» называют свои истории сказками. Это не случайно, повести сборника действительно напоминают волшебные сказки, с характерным для них набором мотивов и ситуаций, которые подробно описал В. Я. Пропп в своих монографиях «Исторические корни волшебной сказки» и «Морфология сказки».

Сказка является отражением мифопоэтического сознания народа. Таким образом, повести «Вечеров...» можно рассматривать как модель мифопоэтической картины мира Н.В. Гоголя, отражающую специфику художественного сознания писателя, которое, несомненно, «подпитывалось» его детскими и юношескими впечатлениями.

В мифопоэтическом сознании женитьба / замужество означало начало новой жизни, возможность продолжить свой род, передать свой опыт, получить социальную определённость в обществе. Однако жениться могли лишь люди, прошедшие обряд инициации, сопровождающийся определённым набором испытаний и ритуальных действий. Об этом подробно писал Е. М. Мелетинский в своей монографии «Поэтика мифа».

Инициация (лат. intio «начинать, посвящать, вводить в культовые таинства», initiation «совершение таинств, мистерий») означает перевод индивида из одного статуса в другой, в частности, включение его в некоторый замкнутый круг лиц, а также обряд, оформляющий этот переход. Обряды инициации называются переходными или посвятительными обрядами. Особенность структуры обрядов инициации - их трёхчастность: все они состоят из выделения индивида из общества (т. к. обряд должен происходить за пределами устоявшегося мира), пограничного периода (длящегося от нескольких дней до нескольких лет) и возвращения, реинкорнации в новом статусе или в новой подгруппе общества. При этом инициация осмысливается как смерть и новое рождение, что связано с представлением о том, что, переходя в новый статус, индивид как бы уничтожается в своем старом качестве; налицо также мифологическая интерпретация обрядового пространства: выход за пределы замкнутой территории, освоенной общиной, приравнивается к смерти [9, 543-544].

В. Я. Пропп выразил предположение, что цикл инициации - древнейшая основа сказки («значительная часть мотивов волшебной сказки отражает обряд инициации» $[6,11])$. В своей книге исследователь подробно описывает мотивное отражение обряда инициации в волшебной сказке, воплощенное в сюжете испытаний, которым герой подвергается в царстве мёртвых, или на небе, или другой стране, населенной злыми духами, чудовищами.

В. Я. Пропп пишет: «Этим обрядом юноша вводился в родовое объединение, становился полноправным членом его и приобретал право вступления в брак. Такова социальная функция этого обряда. $<\ldots>$ Предполагалось, что мальчик во время обряда умирал и затем вновь воскресал уже новым человеком. Это - так называемая временная смерть. Смерть и воскресение вызывались действиями, изображавшими поглощение, пожирание мальчика чудовищным животным. Он как бы проглатывался этим животным и, пробыв некоторое время в желудке чудовища, возвращался, 
Горбацкая О. Ю.

МОТИВ ЖЕНИТЬБЫ В ПОВЕСТЯХ Н.В. ГОГОЛЯ «ВЕЧЕРА НА ХУТОРЕ БЛИЗ ДИКАНЬКИ»

т. е. выхаркивался или извергался <...>. Обряд всегда совершался в глубине леса или кустарника,

в строгой тайне. Обряд сопровождался телесными истязаниями и повреждениями (отрубанием пальца, выбиванием некоторых зубов). Другая форма временной смерти выражалась в том, что мальчика символически сжигали, варили, жарили, изрубали на куски и вновь воскрешали. Воскресший получал новое имя, на кожу наносились клейма и другие знаки пройденного обряда. Таковы в схематическом изложении основные черты обряда» $[10,56]$.

В повестях «Вечеров...» можно обнаружить сюжетную модель волшебной сказки, включающую в себя обряд инициации.

В. Я. Пропп отмечает, что все волшебные сказки начинаются с беды (похищения, нарушения запрета); беде иногда соответствует какая-нибудь ситуация, при которой чего-то не хватает, недостает, иначе, мотив недостачи $[11,180]$.

В повести «Ночь перед Рождеством» мотив недостачи проявляется в том, что Вакула отправляется за царскими черевиками для Оксаны. Стоит отметить, что мотив недостачи в повестях трансформируется в запрет для героя взять в жены полюбившуюся девушку, или, по словам М. Вайскопфа, в отсутствие «санкции на брак». В повести «Сорочинская ярмарка» отец Параски немедленно даёт «санкцию на брак» Грицько и тут же от неё отрекается; в повести «Вечер накануне Ивана Купала» Корж запрещает Петро жениться на Пидорке; в «Майской ночи, или Утопленнице» Левко запрещает жениться на Ганне его отец. Как и в волшебной сказке, в повестях Гоголя завязка сводится к тому, чтобы отправить героя из дома $[11,181]$, побудить его к действиям, которые позволят ему получить «санкцию на брак».

Композиция волшебной сказки определяется наличием двух царств. Одно царство - то, с которого сказка начинается, другое - «тридесятое царство» $[11,182]$, то есть пространство, в котором герой должен будет пройти ряд испытаний для получения награды - согласия невесты на брак или её родителей. Наличие двух пространств в «Вечерах...» отмечал Ю. Лотман в статье «Художественное пространство в прозе Гоголя»: «...нормальным состоянием волшебного пространства становится непрерывность его изменений: оно строится, исходя из подвижного центра, и в нём всё время что-то совершается. В противоположность ему, бытовое пространство коснеет, по своей природе оно исключает движение. Если первое, будучи неограниченно большим, в напряженные моменты увеличивается, то второе отграничено со всех сторон, и граница эта неподвижна.

Оба типа пространства не только различны - они противоположны, составляя в системе «Вечеров...» оппозиционную пару, исчерпывающую весь круг возможных видов пространств. Размещающиеся в этих пространствах герои могут или принадлежать одному из них, или переходить из одного в другое, или попеременно появляться то в том, то в другом [8, 633-634].

«Тридесятое царство никогда конкретно не описывается. Внешне оно ничем не отличается от нашего... Иногда это царство представлено городом. И тем не менее оно все же “другое”. В нём правит грозный царь или царь-девица... Здесь находится... предмет его поисков» $[11,191]$.

Наличие двух пространств бытового и волшебного можно обнаружить в повестях сборника.

В «Ночи перед рождеством» Вакула из родного села попадает в Петербург, волшебное, «другое» для него пространство, которое вызывает у него восхищение своей красотой и великолепием. В этом волшебном пространстве правит грозная, но справедливая царь-девица (Екатерина II), здесь герой добывает предмет своих поисков, черевики, которые носит царица. В повести «Ночь накануне Ивана Купала» иным пространством выступает дремучий лес, в который Петро идёт за цветком папоротника. В «Майской ночи, или Утопленнице» вторым пространством оказываются глубины пруда, в который заглядывает Левко.

В волшебных сказках такой персонаж, как Баба-Яга является стражем на границе двух миров. Вход в мир мёртвых идёт через её избушку, за пределами которой начинается или тёмный лес, или тридесятое царство $[11,182]$. Баба-Яга - эта хранительница входа в иное царство, царство мёртвых.

В «Ночи перед Рождеством» таким пограничным пунктом является хата Пацюка, а сам Пацюк выступает в роли Бабы-Яги - проводницы в потусторонний мир. Пацюк, как и Баба-Яга, обладает особым знанием, он знахарь. Пацюк даёт знать Вакуле, где искать чёрта. В повести «Ве- 
чер накануне Ивана Купала» пограничным пунктом является шинок на дороге, в котором Петро встречается с Басаврюком, в этой повести также присутствует образ Бабы-Яги: «Тут разделил он суковатою палкою куст терновника, и перед ними показалась избушка, как говорится, на курьих ножках. Басаврюк ударил кулаком, и стена зашаталась. Большая чёрная собака выбежала навстречу и с визгом, оборотившись в кошку, кинулась в глаза им... Глядь, вместо кошки старуха, с лицом, сморщившимся как печеное яблоко, вся согнутая в дугу; нос с подбородком словно щипцы, которыми щелкают орехи» $[3,56]$. В «Майской ночи» пограничным пунктом выступает «повалившийся на землю» дом у пруда, похожий на избушку Бабы-Яги, на месте которого хотят строить винницу.

При встрече героя волшебной сказки с Бабой-Ягой еда имеет особое значение. «Приобщившись к еде, назначенной для мертвецов, пришелец окончательно приобщается к миру мёртвых» $[11,66]$.

В некоторых повестях «Вечеров...» переход границы двух пространств сопровождается трапезой героев: «...подумал кузнец, разинув от удивления рот, и тот же час заметил, что вареник лезет к нему в рот и уже вымазал губы сметаною» («Ночь перед Рождеством»); «... потребовал он [Петро] кухоль сивухи мало не с полведра» «Вечер накануне Ивана Купала»)

М. Вайскопф в своей работе указывает помимо трапезы и другие символы временной смерти героя - терновник и узкую тропу: «Терновник - столь же универсальный мистический символ временной смерти, как и узкая тропа, на которую попадает блуждающий гоголевский герой. У Гоголя - это окольный путь, боковая дорожка в лесу или густом саду, спускающаяся к воде границе между мирами и к открытому, разомкнутому пространству инобытия». $[1,83]$. Через «густо разросшийся терновник» по узкой тропе пробирается Петро и спускается к воде Левко.

Признаком временной смерти героя также является безумие, потеря ума, сознания [10, 89]. Вакула теряет свой ум: «Думаю, и не могу вздумать, куда девался мой ум» $[3,113]$; Петрусь становится безумным: «Глаза его загорелись... ум помутился... Как безумный, ухватился он за нож... $[3,57] \gg$.

Герой волшебной сказки достигает успехов без всякого усилия, благодаря тому, что в его руки попадает волшебное средство или волшебный помощник $[11,188]$. Дарителями могут выступать всякого рода старухи или старики, случайно встреченные, которые указывают путь, дарят волшебное средство или помощника, то подсказывают, как его найти $[11,183]$. К числу внезапно появляющихся невидимых помощников может принадлежать и чёрт $[11,190]$. Переправа героя одна из основных функций помощника $[11,191]$.

В роли своеобразного волшебного помощника в «Сорочинской ярмарке» выступает цыган, в «Майской ночи» - панночка-утопленница, в «Ночи перед Рождеством» - Пацюк и чёрт. Пацюк указывает Вакуле, где искать чёрта, а чёрт в считанные мгновения по воздуху переносит героя в Петербург и помогает добыть царские черевики для Оксаны.

После добычи объекта поисков (какого-нибудь предмета, вещи или диковинки), как правило, следует возвращение героя домой. Возвращение иногда принимает форму бегства... Теперь нет помех для окончательной развязки. Герой женится на своей избраннице [11, 192-193].

В повестях мотив возвращения героя домой из «другого» пространства, пространства инобытия легко обнаруживается. Левко возвращается домой с грамотой от комиссара с разрешением на свадьбу с Ганной, после того как помогает панночке изловить мачеху-ведьму. Петро бежит домой, опасаясь погони, после обнаружения клада. Вакула возвращается домой с «черевиками, которые носит царица».

Временная смерть героя ассоциируется со сном, а его пробуждение является свидетельством прохождения инициального обряда и возрождения героя уже в новом качестве.

Левко засыпает и пробуждается на берегу пруда: «Непреодолимый сон быстро стал смыкать ему зеницы; усталые члены готовы были забыться и онеметь; голова клонилась $<\ldots>$ схватил он записочку и... проснулся» [3, 81-83]. Вакула после своего необычного путешествия тоже погружается в непреодолимый сон: «Вакула вошёл в сени, зарылся в сено и проспал до обеда. Проснувшись, он испугался, когда увидел, что солнце уже высоко...» $[3,135]$. Петруся по возвра- 
Горбацкая О. Ю.

МОТИВ ЖЕНИТЬБЫ В ПОВЕСТЯХ Н.В. ГОГОЛЯ «ВЕЧЕРА НА ХУТОРЕ БЛИЗ ДИКАНЬКИ»

щению домой охватывает мёртвый сон: «Два дня и две ночи спал Петро без просыпу. Очнувшись на третий день, долго осматривал он углы своей хаты...» $[3,57]$.

Однако не все герои повестей обретают счастье после свадьбы, руководствуясь сказочной формулой «и стали они жить-поживать да добра наживать». Петрусь после свадьбы с Пидоркой не становится счастливым, «поскольку проиграл главное испытание... его домашнее пробуждение оказывается мнимым, то есть Петрусь не только не воскресает, а ещё глубже погружается в мертвечину: “Одичал, оброс волосами, стал страшен; и все думает об одном, всё силится припомнить что-то; и сердится, и злится, что не может вспомнить...” $[1,106]$. О том, что герой действительно не возрождается в новом качестве, свидетельствует его продолжающееся безумие.

Герой сказки должен обладать определенными качествами. Прежде всего, это качество души, противоположное эгоизму. Это умение понимать состояние и страдание другого существа, сострадание к угнетённым, слабым, требующим помощи. Это своего рода гуманность. Высокие моральные качества героя - не придаток, они органически входят в логику и построение повествования [11, 187-188]. Петрусь не проходит испытания, так как не обладает определенными моральными качествами, которыми должен обладать истинный, положительный герой сказки. Петрусь убивает безвинного Ивася в корыстных целях, и в финале повести герой обречён на гибель.

Итак, сюжеты повестей сборника «Вечеров...» вполне соответствуют схеме волшебной сказки, изложенной В. Я. Проппом, что даёт возможность рассмотреть мотив женитьбы в аспекте мифопоэтических представлений Н. В. Гоголя. По мифопоэтическим представлениям писателя, герой получает «санкцию на брак», то есть возможность создать семью и продолжить свой род, только при условии, если тот пройдёт обряд инициации. Если же герой не проходит определенный круг испытаний и всё-таки вступает в брак - его как несостоятельного в социальном, родовом понятии человека ожидает гибель.

\section{ЛИТЕРАТУРА}

1. Вайскопф, М. Сюжет Гоголя: Морфология. Идеология. Контекст / М. Вайскопф. - М., 1993. - 592 с.

2. Виноградов, И. А. Гоголь-художник и мыслитель: Христианские основы миросозерцания / И. А. Виноградов. - М.: Наследие, 2000. - 448 с.

3. Гоголь, Н. В. Вечера на хуторе близ Диканьки; Миргород; Повести; Ревизор: Комедия / Н. В. Гоголь. М.: Мир книги, Литература, 2006. - 496 с.

4. Гуковский, Г. А. Реализм Гоголя / Г. А. Гуковский. - М.-Л.: Изд-во художественной литературы, 1959. $531 \mathrm{c}$.

5. Гус, М. С. Живая Россия и «Мёртвые души» / М. С. Гус. - М.: Советский писатель, 1981. -335 с.

6. Еремина, В. И. Книга В. Я. Проппа «Исторические корни волшебной сказки» и ее значение для современного исследования сказки / В. И. Еремина. - Л.: Изд-во Ленинградского университета, 1986. - С. 5-15.

7. Золотусский, И. П. Николай Гоголь / И. П. Золотусский. - М.: Молодая гвардия, 1979. - 511 с.

8. Лотман, Ю. М. Художественное пространство Гоголя / Ю. М. Лотман // О русской литературе: История русской литературы. Теория прозы. Статьи и исследования (1958-1993). - СПб.: Искусство, 1997. - С. 621-659.

9. Мифы народов мира. Энциклопедия: 2 т. Т. 1 / гл. ред. С. А. Токарев. - М.: НИ «Большая Российская энциклопедия», 2000. $-672 \mathrm{c}$.

10. Пропп, В. Я. Исторические корни волшебной сказки / В. Я. Пропп. - Л.: Изд-во Ленинградского университета, 1986. - 365 с.

11. Пропп, В. Я. Русская сказка / В. Я. Пропп. - Л.: Изд-во Ленинградского Университета, 1984. - 334 с. 